In Cres. Vol. $3 N^{\circ}$ 2: pp. 365-389, 2012

\title{
ACCESO A CUATRO TEXTOS CONTEMPORÁNEOS ${ }^{*}$
}

\author{
Gustavo Tapia Reyes ${ }^{(1)}$
}

\section{EL CONCEPTO DE LA VENGANZA EN LA NARRATIVA DE CÉSAR OLIVARES ACATE}

Sobre todo después de lo teorizado por Edgar Allan Poe, un verdadero desafío para cada narrador apareciendo en nuestra época, constituye desde hace mucho tiempo escribir cuentos. Nadie, absolutamente nadie, preciándose de alguna vez querer serlo, yendo en una categoría más allá de lo ordinario, puede ignorar las exigencias de una especie por naturaleza sintética, sin precipitarse en el sincretismo de lo concreto, ni menos en el apuro de lo más simple. Nadie como César Olivares Acate (Trujillo, 1979), no obstante, decimos, embarcándose en el afán -siguiendo al maestro norteamericano de los cuentos de terror y de misterio- de unificar temáticamente sus argumentos, alados de pasión, amor, deseo, ternura, nostalgia, agregándole incertidumbre, bajo el más terrible de los membretes, a manera de consecución, según lo pone en evidencia merced a su primer libro en el género narrativo Talión y otros cuentos de venganza (2010). ${ }^{1}$

Desde la primera historia titulada Aparición, narrada en la primera persona del singular, deja entrever la decisión de alinearse dentro de tal orientación temática, a partir de aquello implicando la consecuencia de algo: Ya son varios días que ese perro le viene ladrando a la oscuridad (p.9), instalándose la duda acerca de lo realmente sucedido o como es aceptable esté diciendo eso, especulando con detalles en torno al mismo can, viviendo en la casa abandonada por la madre ante la muerte del padre, junto al narrador, quien sigue allí cual alma en

* Recibido: 10 de julio del 2012; aprobado: 13 de diciembre del 2012.

(1) Licenciado en Educación. Universidad San Pedro. Docente, periodista y crítico. Profesor en la Institución Educativa “Artemio del Solar Icochea” del distrito de Santa. 
pena y puede observar cuánto le rodea. Es decir, si bien parte de un hecho real, trágico, también, en la misma medida, le añade una dosis de fantasía, atenuando su truculencia o acaso potenciándola. O en el relato Persecución, donde en un principio se entremezclan dos planos: en el primero, el sacristán del templo teme por su seguridad al ver a un hombre furioso reclamándole al sacerdote: $n o$ debo salir de este confesionario ¿Y si le pega al padre? (p.13), en el segundo, la mujer de aquel se deprime ante la muerte del hijo y, no habiendo acontecido el milagro, ya resignada, dice: ha sido tu voluntad divina y eso no se discute (p.14), después, un tercer plano se inmiscuye en la historia, perteneciendo al marido, quien azuza a la mujer dé muerte al emocionado sacristán, a quien considera el culpable de todo: seguramente erecto y aún incrédulo por tanta dicha, no sospecha lo que está por venir (p.17).

Igualmente la venganza se halla implícita en el expresivo Talión, cuyo título presta a una gran parcela del conjunto, por cuanto, no todos los cuentos, en el sentido estricto, abordan dicho tema. El desesperado monólogo pertenece a una mujer clamándole al marido: nuevamente estoy llamando a la puerta como a ti te interesara abrir (p.19), aunque éste, revanchista, molesto, rencoroso, permanecerá sordo, sin contestar ni mover un dedo, literalmente, pues se encuentra postrado en una silla de ruedas, incluso la mujer le asevera e implora: nunca más te diré inútil, miserable, bueno para nada. Es más, si quieres me arrodillo ante ti (p.21), antes de verse atacada y arrastrada hacia un auto por desconocidos. O en el desechable $\boldsymbol{P} \boldsymbol{a}^{\prime}$ bravo, yo, donde en primera persona el narrador, el único profesional de la familia (p.50) cuenta su retorno al barrio, encontrándose con el tío Nilo bebiendo en un bar de mala muerte: le advertí, solo un vasito nomás, como para no despreciar (p.48), siendo presentado a varios delincuentes que se hallaban en la misma mesa, entre ellos uno apodado Perdigón, quien se daba tres golpes de pecho por cada una de ellas (las cárceles mencionadas), orgulloso (de haber estado allí) (p.53), terminando también embriagado como en ningún momento le había pensado sucedería.

No se hace ascos tampoco Olivares Acate en asumir el pestilente como desagradable tema de la zoofilia, tan común en la zona sierra, según se conoce, aunque ello de ningún modo quiere decir pueda no suceder en la costa. Aquí se insertan, por una parte Llamada de atención, abordando en tercera persona las relaciones entre el cholo Feliciano y una burra de su propiedad, a la cual recrimina cual si fuera una mujer: Carmela!, cómo se te ocurre hacerme esto (p.33), debido a que dicho cuadrúpedo, al verlo borracho, se pone desobediente e inamovible, obligándolo a rogarle piedad, no debería ponerse celosa, todo porque 
alguna vez se me ocurrió llevar una cholita para que durmiera conmigo (p.36), inclusive le recuerda su comportamiento en el día de su boda; pero, como producto, a este relato le sobran algunas frases demasiado explicativas, cuando debieron quedar en tácitas y, por otra parte, Mimí, cuya primera versión podemos encontrarla en Jeremiadas (2009), un volumen previo del mismo autor, versa sobre las relaciones también degradantes entre un joven, considerado tonto, de nulo hablar y una perra de tal nombre: Ahora meto mi mano brazo por su entrepierna y la traigo hacia mí. Ella no deja de lamerme la cara (p.25),

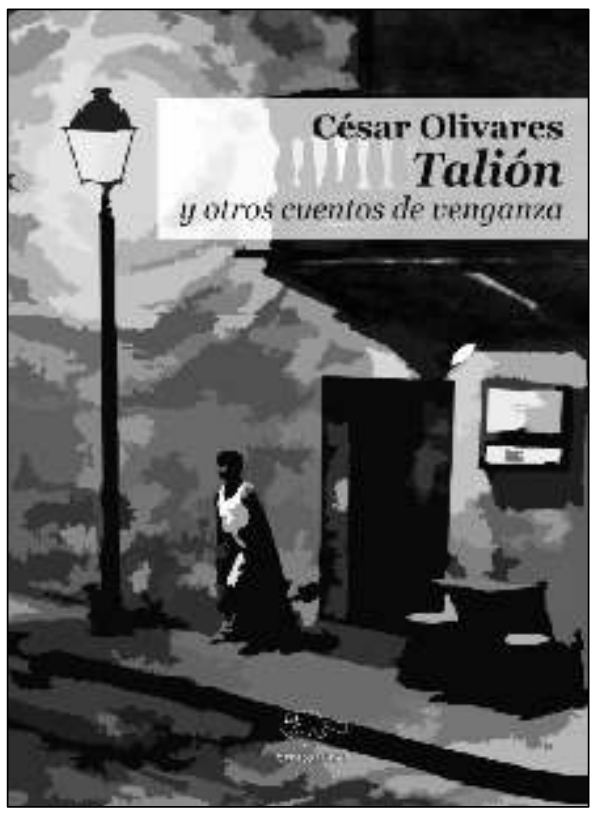
añadiéndose Ultraje que, mediante la vuelta atrás en el tiempo, terminando en el mismo punto, narra en tercera persona, la violación de una muchacha ante los ojos de su hermana Camila quien, desesperada, nada podrá hacer por defenderla, a causa del desenfreno en alcohol y drogas mostrado antes por aquella: Dos jóvenes hombres, ubicados en los asientos traseros, forcejeaban con una muchacha que aparecía semidesnuda (p.39). Pudo ser este relato uno de los perfectos de Talión y otros cuentos de venganza, quedarse internado en nuestra psiquis de manera permanente, mas, ciertos descuidos en el empleo de algunas frases, acaban con el avizoramiento de lo posible.

Al lado de aquellos, engarzados dentro del tema general propuesto por César Olivares, conceptuándolo dentro de sus distintas acepciones, surge también Cómo tú lo estableciste, título haciéndonos recordar a un poema de la precozmente fallecida poeta María Emilia Cornejo, en realidad, constituye todo un sentido homenaje perpetrado por el narrador a su tía (real o ficticia) de nombre Pocha, quien: No quiso que su cuerpo fuera abandonado en una fría y sórdida pared de pabellón (p.61), habiendo evidenciado a lo largo de su vida una fuerte catadura moral para enfrentarse a la pobreza y otras dificultades, desatando el dolor en los demás: Quienes la vimos partir lloramos por ella (p.62), aunque después le vendrá la resignación ante lo inevitable. Situación semejante se da en Quédate conmigo donde, en primera persona, el protagonista narra la agonía de 
su mujer tendida en la cama de un hospital, después de haber tomado una poción de insecticida disuelta en Coca Cola (p.27-8), abriéndosele una serie de reflexiones acerca de tal posibilidad, por ejemplo, el miedo a quedarse solo, sin dejar entrever la irrupción del elemento sorpresa, dándole otro curso a la historia, porque la susodicha mujer es solo una muñeca de trenzas largas por la que (la niña) Sofía llora inconsolablemente (p.31); aunque, al mismo, de igual manera le faltan algunas frases del indispensable redondeo, sugerir no consiste únicamente en eliminar sin ton ni son, formando así la pentalogía de aquellos relatos que bien pudieron culminar siendo perfectos si no fuera por el "casi" impidiéndoles, debido a tamañas distracciones.

Por eso, ninguno de los arriba mencionados, se aproxima siquiera en parte a Desaparición. Resulta éste siendo un buen relato que narra la historia, en la primera persona del plural, de Jerónimo Céspedes quien, pensando dejar a Yolanda, porque: Los escritores no deberían tener hijos, compadre, sufrirían demasiado, dijo (p.67), después de tres días es encontrado muerto en la habitación donde vivía, los amigos sospechan de aquella, admitiendo haber tenido una discusión, nada más, no dejándolo así como lo hallaron: con la cabeza metida por completo en el inodoro y rígido en el extremo (p.70), menos esperándose la reacción de aquellos envolviéndolo en una sábana para sacarlo cuanto antes de allí, suponiendo las cosas proseguirían sin mayor sobresalto. Ni tienen algún atisbo de Servicio nocturno, el mejor de los textos pertenecientes a Talión y otros cuentos de venganza, con un final exacto y contundente, narrado en la tercera persona del singular, impidiendo al lector permanecer tranquilo ante la decisión tomada por Alexandra, una joven de veintidós años de edad, que siempre fue la primera en todo y el alma más noble de su familia, ahora se convertiría en la criatura más perversa (p.58) entregándose a un varón especialmente contratado, a quien: nunca le habían pagado tanto por acostarse con una mujer tan hermosa (p.57) para, acabando voluntariamente con su virginidad: era el momento de demostrar lo que podía hacer (p.59), vengarse de su madre, a la cual despreciaba tanto como a su padre.

Empero, debemos afirmar, sin temor a equívoco, que el cuento titulado $\mathbf{L a}$ sospecha es el mejor de todos los anteriores, en todos sus extremos. Ni siquiera los dos últimos alcanzan a rozar la dimensión inserta en éste, cargado de un tinte policíaco y desorientación psicológica, donde aparecen los personajes siendo movidos por sus bajas pasiones. En la tercera persona de un observador externo, presenta a Rafael, inmerso en la angustia de acaso llegar a ser padre, no considerando todavía sea el momento adecuado: Nadine llamó algunas semanas 
después de haber terminado su relación, para contarle que su menstruación se le había retrasado (p.72), por lo cual, arma todo un tinglado, oculto en la apariencia de una cita amorosa donde, luego de darse la estratégica reconciliación, beberían unos tragos y él esperaba aprovechar la situación para embriagarla, no pensando que Nadine, se enteraría de todo leyendo un mensaje hallado en su celular: así será más fácil aplicarle el sedante y bajarle el chibolo (p.75), ocasionado un cambio repentino en ella, quien opta en ser fría y el final del relato, ubicado dentro de la misma línea de lo desconcertante, no explicando más nada, solo añade lo actuado: antes de sentir la botella de ron quebrándose en su cabeza (p.78), dejando todo lo restante para la imaginación, a manera de pregunta pertinente: ¿cómo reaccionó Rafael a posteriori después de haber recibido el golpe?

Una de las falencias latentes en Talión y otros cuentos de venganza es el apuro manifestado por Olivares Acate en la publicación de los mismos. No habiendo efectuado una cuidadosa limpieza de frases hechas o de consumados ripios, permite, por ejemplo, que Ultraje, Como tú lo estableciste, Quédate conmigo, Llamada de atención, Aparición jamás logren el nivel estético para el cual parecían estar especialmente destinados. Se queden apenas en la promesa de cuánto pudieron ser si hubieran quedado libres de expresiones como: "también estaba untado de esa baba pestilente con olor a lejía pasada, sobre todo la tanga" (p.43), donde cae en exceso la última parte; "Descansa en paz, tía Pocha" (p.64), una cuestión de índole fraternal, narrador igual sentimiento hacia el otro, completamente desfasada; "vieron, con cierto beneplácito burlón" (p.37-8), o sea, se alegraron y, al mismo tiempo, se burlaron de aquel personaje, tal vez sonando bien de manera autónoma o sacadas del entorno semántico, no así dentro del conjunto argumental donde, se supone, deberían funcionar en gran medida. Distinta aunque similar situación se presenta en los casos de Talión, Persecución, Mimí, Pa' bravo yo, por cuanto, al sumergirse en las historias narradas brota la sensación de estar en perfecto estado de planteadas, vistas desde cerca o desde lejos que, no obstante, en el momento de terminar de leerlas, queda la inmensa desazón de "algo" estar faltándole o sobrándole acaso, una frase por allí, un detalle adicional, cerrando o ampliando el circuito de lo ficcional.

De todo ello deriva otro problema hallado en el volumen de quien también es autor del poemario La vestimenta de los días (2009): la confusión entre la escasez de tiempo que tiene todo narrador para hacer fluir una historia con la rapidez a ser usada como un ingrediente insoslayable de todo relato. Esto es, la enemistad del tiempo narrativo no implica mezclarlo, absorberlo, menguarlo 
con la rapidez y brevedad en los detalles, de modo tal que las historias de Aparición, Ultraje, Mimí, Persecución, Como tú lo estableciste, Talión, Llamada de atención, Quédate conmigo, $\boldsymbol{P a}^{\prime}$ bravo yo parecen haber sido escritos por quien estaba en la víspera de ducharse, tomar el desayuno y salir presuroso al centro de trabajo y no por quien, reposado, cuidadoso, tranquilo, va revisando cada cláusula expresiva con una morosidad de filigrana como quería Gustavo Flaubert. Es aquí donde salta el tino del buen narrador cuando, abandonando esos ribetes ajenos, se propone ser más sosegado en su concepción, entonces el lenguaje se transforma en el más perfecto de los vehículos para ir atrapando el lector en la trama engañosa, ir quitándole las defensas a fin de colocarlo bajo su entero servicio, someterlo a cada una de las exigencias hasta, yendo de menos a más, alcanzar el clímax en los relatos correlativamente titulados Desaparición, Servicio nocturno, La sospecha, obteniendo así una rigurosa autonomía dentro de la ficción misma.

Hay entonces mucho pan todavía por rebanar en la narrativa de César Olivares Acate. Una primera aproximación a la especie, desarrollando el concepto de la venganza a modo de tema básico, no implica emitir un juicio valorativo, exento de exigirle calidad como hipótesis de trabajo, en la medida que si el autor de lentes ahumados, apuntando con una metralleta de utilería (conforme aparece fotografiado en la solapa de su libro) prosiga empeñado en ser quien alcance la cumbre, nadie va a detenerlo, ni aun estando cuesta arriba, porque a todas luces se descubre tiene un talento indudable para enfrentar las historias, acosándolo en silencio. De ninguna manera puede quedarse circunscrito al extremo donde ahora se encuentra, ni pensar en corregirse sin asumir la necesidad de echarle una mirada al entorno, antes de hallar la más adecuada forma de abordar una especie tan difícil y complicada. Debe considerar no es el primer cultor ni será el último en nuestro país de Julio Ramón Ribeyro, Oswaldo Reynoso, Eleodoro Vargas Vicuña, entre los consagrados o de América Latina, Augusto Monterroso, Julio Cortázar, Jorge Luis Borges como los grandes maestros. De tales nombres, cada quien está obligado de partir cuando se aspira a ir más allá de ser un narrador meramente episódico o epigonal.

\section{NOTAS}

1 OlIVARES, CÉSAR. Talión y otros cuentos de venganza, Ornitorrinco Editores, primera edición, octubre del 2010, 78 páginas numeradas. En esta edición nos hemos basado para obtener las citas del presente ensayo. Nacional del Santa. 


\section{REALISMO HISTÓRICO Y MÁGICO EN LA NOVELA LOS APUNTES DE ALEJANDRO DE BRAULIO MUÑOZ}

Precisa la técnica de yuxtaposición de los capítulos, numerados en romanos, empleada por Braulio Muñoz Terrones (Chimbote, 1946) para dar verosimilitud a su novela Los apuntes de Alejandro (2009) - LAA en adelante- ${ }^{1}$ y así, junto a la anterior Alejandro y los pescadores de Tancay (2004) -APT en adelante, prologada por el estudioso italiano Antonio Melis, formando a la fecha una especie de bilogía, proseguir literariamente configurando la historia de la ciudad ahora denominada "capital mundial de la pesca y el acero", su tierra natal, de donde emigrara como tantos miles para residir desde 1968 en los Estados Unidos. Esta vez, le da un curso mucho mayor, adicionándole una variedad de anotaciones hechas por quien sería la, real o imaginaria, editora de la novela, al corpus general de la misma, integradas por la presentación y descripción de cada uno de los personajes, experimentando una variedad de experiencias, en distintas situaciones, a las cuales se vieron sometidos en el largo transcurso de sus agitadas vidas.

Sin embargo, digámoslo ahora, Muñoz Terrones no va hacia adelante de acuerdo a la cronología natural de todo proceso evolutivo sino más bien como en el maravilloso sétimo arte, inventado por los hermanos Louis y Auguste Lumière e impulsado más tarde por Georgies Méliès, va hacia atrás, retrocede, efectúa un prolongado recorsi para desarrollar lo que en el cine constituiría una "precuela". Es decir, el antecedente inmediato o lejano de otra película. Pone repentinamente un freno en lo avanzado y se equidista solo en parte de APT para, centrándose sobre todo en el embrión de cuanto pudo ser un abultado paquete de papeles denominado "Cuaderno Azul", de rayas rojas y delgadas, que llevaba un sello de agua de la librería Minerva (p.15), escrito por el protagonista Alejandro Moscoso Huamán, dejado en poder de quien, bajo muchas reticencias, decide publicarlo en forma de una novela, aun cuando: después de todo, novela sigue siendo novela (p.11), haciéndole unas ligeras modificaciones para darle el indispensable vuelo de la ficción, a través de los treinta y siete capítulos (APT posee uno menos), la previa "Introducción" a cargo de quien, se supone, decidió ordenarlos con la previsión de una experta, describiendo lo arduo de haber afrontado dicha labor: Contenía muchas páginas que, a pesar de todos mis esfuerzos, no he podido descifrar (p.15) junto a un "Epílogo", en gran medida desencajado, pues, no aclara ni afirma nada más allá de lo desarrollado en las 218 páginas de esta fascinante novela. 
A partir de allí, $\boldsymbol{L A A}$, teniendo en la portada una fotografía de Nancy K. Muñoz, con el diseño de Marina Guillén y las ilustraciones del pintor Teófilo Villacorta, comienza su desenvolvimiento a manera de una espiral incontenible que va aclarando, precisando o ampliando distintos capítulos, nunca todos, de la primigenia APT. No decimos haya una dependencia con ésta sino manteniéndose autónomas, se enriquecen de manera mutua y se tornan inseparables dentro de un afán por entender el contexto histórico, social, cultural, político e incluso económico (en gran parte eliminado por la editora, se nos informa) de Chimbote en los años 60, época cronológica correspondiente a ambas novelas. Aparecen los capítulos I, XIV, XVIII, XXI y XXV presentando las acotaciones de aquella en letras pequeñas, entremezclándose con los fragmentos recogidos y modificados en letras grandes, respecto a la existencia en el puerto del antiguo como pujante Mercado Modelo y la Casa del Niño Chimbotano (de la cual el propio Braulio Muñoz fuera dirigente en sus años mozos), el funcionamiento de la no menos famosa Casa Rosada, cada vez más arrinconada por el avance de la quincuagenaria Urbanización El Trapecio: hasta que la empujaron más lejos todavía, por los arenales de Tres Cabezas (p.116), donde hasta hoy funciona; la gran cantidad de casas de un primer o un segundo piso donde se ven: paredes a medio terminar, columnas solitarias con alambres que parecen cerdas de chancho serrano (p.132); la Estación del Ferrocarril, ubicada entre Leoncio Prado y la avenida Gálvez, destruida durante el terremoto del 31 de mayo de 1970 -acontecimiento desencadenante en APT-, prestando servicios con destino a la zona de Huallanca (sierra de Ancash); algunos personajes de entonces, llámese el reconocido señor Morachimo, vendedor de diarios y revistas aún ahora, quien fue y sigue siendo toda una institución (p.34), otros aromas propios del puerto: El punzante olor a la anchoveta hervida (p.206) y demás rincones próximos todavía o lejanos podría ser, junto al capítulo VI, con la sumersión en el pasado remoto de Chimbote hasta los tiempos de las culturas preincaicas, cargando todo su misterio: las máscaras de nuestros dioses sirven para ocultar sus ausencias (p.46).

Como resulta obvio hay capítulos circunscritos al personaje principal de $\boldsymbol{L A} \boldsymbol{A}$ y, de hecho, también de APT. En el III se habla de las lecturas preferidas por Moscoso Huamán, entre ellas El corsario negro (1898), novela del casi olvidado Emilio Salgari; el XXIV refiere a la renombrada Villa María, donde vivió, escenario principal de APT, uno de los más antiguos pueblos, entonces perteneciente al distrito de Chimbote; el XXVIII muestra al protagonista con sus amigos Morachimo, Gabriel, entre otros, pretendiendo enrumbar a Trujillo 
a fin de participar en las revueltas populares, meta después abandonada (recordemos en APT Alejandro Moscoso acaba muerto durante una represión policial, acusado de subversivo en busca de justicia). O los capítulos XXX y XXXI cuando Alejandro habla con don Morales, mientras éste pescaba: Aproveché para preguntarle qué estaba picando (p.183) y doña Pelagia: me hacía sentir como si me hubiese estado esperando (p.194), dos personajes claves en APT que acaban diseñados o perfectamente definidos en $\boldsymbol{L A A}$, cerrando con el cuerpo del protagonista siendo velado en una casa del Asentamiento Humano San Pedro, el llamado "balcón del puerto", de mala fama debido a la delincuencia imperante; no faltando tampoco la inserción de una serie de notas de pie de página, dispuestas para aludir a otras novelas abordando similar tema o conceptuar a determinados personajes, no directamente apareciendo en ninguna de las dos novelas como el poeta Octavio Paz (p.30), el saxofonista Charlie Parker (p.40), el guarachero Daniel Santos (p.116) o el narrador chimbotano Fernando Cueto, sobre quien se lanza un elogio de polémica objetividad (p.116), hasta se agrega una alusión al trabajo de la Comisión de la Verdad y la Reconciliación (CVR, p.130), este dato era natural tratándose de un personaje protagónico con esos perfiles.

Indudablemente en la creación de éste ha incidido mucho la propia existencia de Braulio Muñoz Terrones, de quien Alejandro Moscoso Huamán presenta muchos retazos, líneas, rasgos biográficos en común. Es una especie de alter ego del autor, creado adrede bajo el propósito de hacerlo pasearse a sus anchas, casi como aquel narrador empleado por García Márquez en Crónica de una muerte anunciada (1981), entre los distintos capítulos conformantes de $\boldsymbol{L A A}$, evocando de arranque: Lo primero que Gabriel y yo hicimos al llegar al Ateneo de la Juventud fue preparar nuestro té de hierba luisa (p.30), dejando entrever los asideros de por qué debió salir con urgencia de nuestro país: De no haber visto la necesidad de unirme a la lucha del pueblo, tal vez seguiría andando por las calles de Chimbote (p.42) o cuando quiere comprometerse políticamente integrando un grupo voluntario: La idea de prepararnos para milicianos nos iluminó una noche calurosa de marzo (p.165), habiéndose enfrentado muchas veces a la policía y a la soldadesca: Caminamos al encuentro de los Uniformados unos treinta metros (p.156) e incluso, una vez emigrando, no tiene ningún miedo convertirse en cosmopolita, adaptarse al medio donde le tocó vivir: Después de un recorrido por varios países -sobre lo cual yo no sabría decir más, porque él hablaba de esas experiencias con mucho recelo- Alejandro terminó en París (p.100), aunque: Cuando regresó a Chimbote disfrazado de mujer 
(p.181), un episodio igualmente sucediendo en APT antes de acabar muerto, dejando así establecida su condición de acosado, de proscrito, de subversivo.

También se hallan los capítulos duales. En el VI se reseña la presencia de lo tenebroso formando parte de la naturaleza marina: Era más bien miedo al proceso de morir, al ahogamiento (p.52) -nótese el miedo es un "ingrediente" exterior afectando el mundo interior de cada personaje, sea en $\boldsymbol{L A A}$ o en APTsimilar en el XIII haciendo mención de lo mismo en la acera: El miedo siempre viene acompañado de emociones correlativas como la impotencia (p.80), donde se manifiesta extendiendo sus tentáculos de imperecedero equinoccio hasta volverse concreto. $\mathrm{O}$ en el capítulo $\mathrm{X}$ se indica a una tal Justa Consuelo con quien el protagonista se encuentra en un inicio en Tancay: cuando nos conocimos ella tendría sus treinta años y yo ni siquiera veinte (p.68) y en el XI, estando después en la urbanización El Trapecio, el erotismo fluye: me condujo de la mano hacia un dormitorio pequeño donde había una cama ancha con mosquitero (p.77). Son duales también los capítulos IV y V, haciéndose una referencia directa a María Elena, la pareja más estable de Moscoso Huamán y otro personaje clave en $\boldsymbol{L A} \boldsymbol{A}$ para comprender a cabalidad la gestación de esta novela, toda vez que acabará siendo la única depositaria del no menos aludido "Cuaderno Azul", entregado por el mismo Alejandro antes de partir hacia el extranjero, despidiéndose en el capítulo XXXVI: se apartaba ligeramente de mi lado mientras caminábamos por el malecón, dejando que un espacio nuevo creciera entre los dos (p.211) y recibiendo la última carta de Alejandro en el capítulo XXXVII, donde éste, emocionalmente más recuperado de todo lo anterior, le decía: Qué lindo que te esté yendo bien en Chimbote. No me sorprende. Tú siempre has tenido arranques de bailarina (p.217).

Algunos capítulos están dedicados a presentar personajes meramente episódicos o estrambóticos en sus maneras de interactuar con los demás: el Gran Machiste, quien pretendiendo demostrarles el funcionamiento de una imposible "pistometralla" acabará teniendo las cejas chamuscadas y la cara cubierta con un polvo gris (p.63); el músico Albita, cuya característica básica radicaba en a pesar de ser un jaranero hasta amanecerse, siempre abría su puesto a las siete en punto (p.92); el tantas veces personaje de otras novelas don Ciriaco Moncada, visto a través de los recuerdos ( $\boldsymbol{L A A}$ también se ampara en esta facultad humana trasladada a lo escrito en relación a APT), por una parte como deslucido: pantalones negros, raídos y sucios atados a la cintura con soguilla deshilachada (p.176) y, por otra siendo pulcro: pantalones de casimir y camisa blanca que hacen resaltar su cara morena (p.146); el ingeniero Banjaco, quien sabiendo de 
sus andanzas en procura de organizar a los trabajadores de construcción civil en el valle de Santa, rotundo, le dirá al protagonista: Te aprecio porque eres demasiado inocente para ser cojudo, Alejandro (p.217); la enfermera Judith Bartlett, nacida en Vermont (zona noroeste de los Estados Unidos), una anterior pareja de Moscoso Huamán, obligados a separarse a causa de la mala reputación de éste, empero: En los pocos meses que pasamos juntos nos dimos el uno al otro la oportunidad de descubrir lo maravilloso que es el amar (p.105) y el padre Parker, siempre mostrado con su personalidad represiva, a partir de su fe católica luchando contra el pecado, tanto en $\boldsymbol{L A} \boldsymbol{A}$ : Su no muy bien camuflada amenaza me dejó aturdido (p.111) como en APT donde es el personaje impulsador de una manifestación haciendo temblar a La Cabra, dueña de un prostíbulo. ${ }^{3}$

Esto significa que, en $\boldsymbol{L A} \boldsymbol{A}$ conforme sucedía en APT, no hay tampoco un argumento central evidente, organizador de los capítulos y, acorde a la técnica narrativa manejada por Braulio Muñoz, semejante a cuanto pasa en La serpiente de oro (1935) de Ciro Alegría Bazán o en la póstuma El zorro de arriba y el zorro de abajo (1971) de José María Arguedas, cada personaje contribuye al conjunto, a partir de su propia historia e individualidad. Todos a una como en el célebre drama del español Lope de Vega o la forma desbordada en que una turba apedrea o incendia un edificio, aunque, en la misma novela, ninguno queda al margen de nada, sea desde el personaje principal Alejandro Moscoso, pasando por quienes están relacionados directamente con él: María Elena, Justa Consuelo, Judith Bartlett, don Morales, personaje narrador de APT, doña Pelagia, esposa de éste; llegando a los personajes secundarios, nunca descartables, por cuanto constituyen valiosas fuentes de información sobre las andanzas de Alejandro: Morachimo, Gabriel, el propio Machiste, Rosa, Angélica, Genaro; terminando con los naturalmente episódicos: Aurelio Cervantes, Raquel Santayana, Fernando Agüero, Lalo, el Capo Willy, Albita, el Cholo Huaraz, Boquejarro, entre otros que, sean reales o imaginarios,

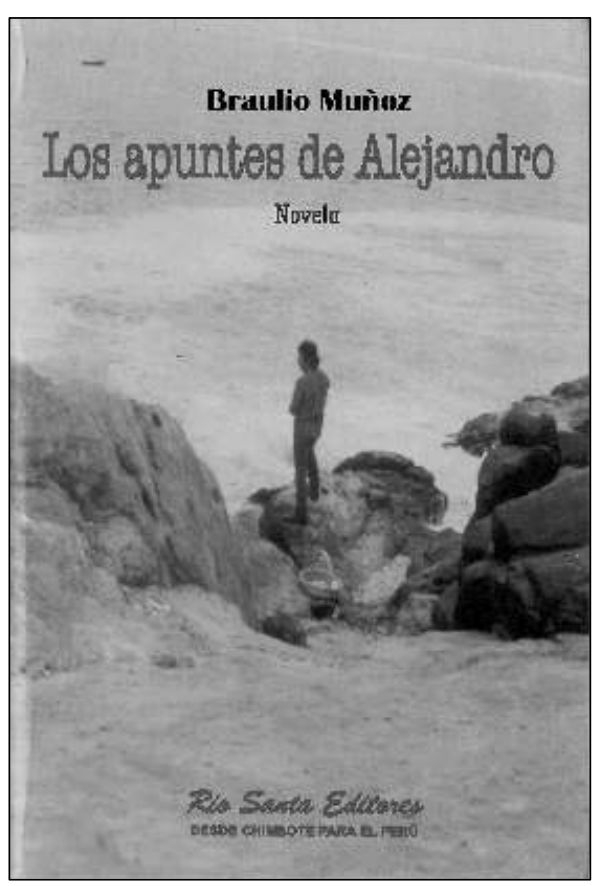


igual son personajes participantes de la amalgama histórica sustentada por $\boldsymbol{L A A}$, acabando fundidos de manera formidable llegando a integrarse y enriquecer la memoria del puerto, de la cual también congrega, empezando desde su propio subtítulo, la anterior APT. ${ }^{4}$

Lo hasta aquí expresado puede llamar a confusión: no vaya a creerse que $\boldsymbol{L A A}$ es un apéndice o, a lo mucho, una ampliación regularmente planteada de APT. Podemos afirmar se trata de una novela donde, en paralelo a complementar, profundiza también en la psicología, en la ideología, en las costumbres, en el periplo vital y en la experiencia amorosa del personaje principal que, en APT, solo aparece velándose dentro de un ataúd, receptor inaudito del largo monólogo emitido por don Morales, permitiendo entender las razones de hechos como el entierro de Alejandro y el carácter de personajes alternos, asumidos por doña Pelagia y el tal Genaro. De allí proviene la importancia de haber contextualizado al puerto de Chimbote en toda su extensión territorial e incluso en sus lugares más específicos: la playa El Dorado, las urbanizaciones El Trapecio y Buenos Aires (no existía el ahora distrito ecológico, cultural y emprendedor), los colegios "Santa María de Cervelló" (donde estudiaban solamente mujeres), "Mundo Mejor", "Erasmo Roca” (en ese entonces únicamente nocturno), la Casa Rosada (donde el protagonista de $\boldsymbol{L A} \boldsymbol{A}$ debutara sexualmente), el Malecón Grau, el Hotel Chimú, el Mercado Modelo, las avenidas Bolognesi y Gálvez, el casi extinto Cine Chavín, el Restaurante "Venecia" y los desaparecidos "San Remo", el restaurante para pitucos que quedaba en la esquina sur de la Plaza de Armas (p.151) o la Academia Comercial "San Luis Gonzaga", además de otras provincias mencionadas desde Casma y Virú hasta Huancayo, bastante cambiadas en nuestra época, por lo tanto: Alejandro nos regalaba estampas bañadas en añoranza (p.12), aceptables en la medida de cuanto el excéntrico, pero, siempre acertado Ramón del Valle-Inclán afirmaba que las cosas no acaban siendo como las hemos visto sino conforme las recordamos.

Cabe destacar aun estando frente a capítulos de una prosa libre de ataduras lingüísticas y plena de expresiones castizas, hay también otros integrados de poemas mostrando una versificación bastante endeble, forzada y pétrea respecto a los diversos temas o aspectos contenidos en $\boldsymbol{L A A}$, apenas ilustrativos en unos casos o referenciales a otros. Tenemos el capítulo XII, el capítulo IX, al capítulo XXV mencionando al no menos conocido Malecón Grau antes de las últimas refacciones, que le han dado una apariencia más contemporánea; resultando de una inevitable mención especial el capítulo XXXII, subtitulado "Trozos de una filosofía", pues allí se explica con claridad el por qué de muchas posi- 
ciones ideológicas y prácticas del protagonista a lo largo de $\boldsymbol{L A A}$ como de, siguiendo la cuestión cronológica, la anterior APT: Para nosotros los humanos, no hay verdades eternas. Todo cambia en nuestro mundo. Una verdad de hoy puede desaparecer. Otras nacen (p.200) y el capítulo XXIII denominado "La barricada" donde se especifica el concepto de libertad que: mama de la ira y la esperanza (p.145-6), manejado por aquel, siempre en relación a los demás y la presencia de uno de los personajes más populares del puerto (junto al Loco Moncada), la tía Sara Sarandonga, por su apego natural a las luchas o manifestaciones de los obreros, aunque hay también en el capítulo XX una frase de Alejandro Moscoso refiriéndose a las imágenes evocadas, susceptible de ser configurada como esencial en $\boldsymbol{L A A}$ y hacerla extensiva, a modo de poética, al resto de la novela: precisamente por desagradables, esas imágenes tienen la virtud de reconectarme con mis ideales (p.125) o el racconto, no tan extenso, del capítulo XXII versando sobre el protagonista viviendo en un distrito, ubicado en las afueras de Lima hasta el año 1950 aproximadamente ${ }^{3}$ : En ese lindo valle aprendí muchas de las cosas que me han acompañado en todos estos años (p.136), antes de su retorno a Chimbote.

En lo restante, Muñoz Terrones ha demostrado con $\boldsymbol{L A A}$ que los caminos de la novela no están agotados, según en algún momento se creyó o se dijo que después de las unánimes En busca del tiempo perdido (1913-1927) de Marcel Proust, Ulises (1922) de James Joyce, El sonido y la furia (1929) de William Faulkner, Sobre héroes y tumbas (1961) de Ernesto Sábato, La muerte de Artemio Cruz (1962) de Carlos Fuentes, Rayuela (1963) de Julio Cortázar, Cien años de soledad (1967) de García Márquez, prácticamente no había nada más por realizar o hacer en el género novelístico, cuyos orígenes se remontan a la propia India de Mahatma Gandhi. Se consideró estar en el tope de posibilidades para seguir explorando en busca de hallar nuevas formas de ensamblar un argumento o varios argumentos en uno solo (como sabemos los temas prosiguen siendo los mismos a través de todas las épocas) hasta que la aparición de Si una noche de invierno un viajero (1979) de Ítalo Calvino, La insoportable levedad del ser (1984) de Milan Kundera y Los detectives salvajes (1998) de Roberto Bolaño echaron por tierra este supuesto, originando un nuevo impulso donde aquella devino en una especie cultivada en todas las literaturas del mundo, mientras Chimbote continuó siendo una metrópoli al margen de aparecer reflejada en alguna novela, conforme había pasado con Nueva York en Manhattan transfer (1925) de John Dos Passos, Dublín en Ulises de Joyce o cientos de veces con París entre los novelistas del siglo XIX. 
Con el objetivo de alcanzar esto Braulio Muñoz no recurrió al periodo de los años 60, dentro del denominado "boom", ni se adentró en la tradición de la narrativa universal, sino, calando en lo más alto del Indigenismo, aparecido en nuestra literatura durante las primeras décadas del siglo XX (a diferencia de García Márquez quien señaló haber aprendido a descifrar el trópico leyendo a Graham Greene), logró encontrar el adecuado camino por dónde debía abordar la realidad porteña, solventada en muchos siglos de historia perdiéndose en el tiempo. Empeñado en la depuración de la misma, pudo centrarse en el ámbito de cuánto mejor conocía $\mathrm{y}$, en consecuencia, desenvolverse dentro de una mayor como eficaz soltura. Lo realizó de manera brillante en su primera novela APT y ha terminado -esperamos en forma jamás definitiva- con esta $\boldsymbol{L A} \boldsymbol{A}$ demostrando un talento innato para captar la esencia de lo anteriormente sucedido. No de otro modo ha procedido quien es $\mathrm{PhD}$ en Sociología por la Universidad de Filadelfia y desde 1978, profesor en el Swarthmore College de la misma ciudad norteamericana, donde ha ocupado los cargos de Jefe de Estudios Latinoamericanos y Decano de Ciencias Sociales, aparte de otros, para darle la indispensable estructura a esta novela teñida de chimbotanismo en cada una de sus páginas. Tomando como base a El nombre de la rosa (1980) de Umberto Eco, Braulio Muñoz le ha dado una variación a no ser él quien edita ese manuscrito del siglo XIV encontrado de casualidad sino el otorgante del "Cuaderno azul" a quien fuera la mujer del protagonista para hacer de ésta la encargada más decidida en publicar las "memorias" no apócrifas dejadas por aquel ¿revoltoso? ¿guerrillero? ¿terrorista? desaparecido.

La condición de anterioridad en la ficción o la realidad para explicar a esta novela sirve de excelente pretexto en la afirmación de algunos datos. Similar a objetos lanzados desde una prudente distancia van a dar en el blanco de cuanto quedó pendiente en APT, estableciendo una alianza de vasos comunicantes en perpetua alimentación y clarificación de los sucesos narrados, dentro de una perspectiva apuntando a reflejar el habla propia de los nacidos o emigrados en o a esta parte del orbe llamada Chimbote: Que te apures me dijo, nañito (p.209), Es más fácil que salir al mar o sentarse en las rocas con su cordelito (p.141), Boquejarro -me dijo Lalo de su amigo, con su sonrisa leve de siempre-dice que está picando como pagado (p.48), saltan a guisa de ejemplos. Se entiende con ello el afán morosamente memorístico de Muñoz Terrones, desarrollado en ambas novelas, procurando no dejar nada a la imaginación, para continuar develando la realidad del puerto, tan venida a menos en las últimas décadas, empezando por abrir fuego contra la pesca destructora del paraíso en otros tiempos y prosiguiendo con el (casi) mítico, heroico Alejandro Moscoso Huamán orien- 
tando, organizando a los trabajadores, dirigente sindical metiéndose en un sinnúmero de problemas, los uniformados cuanto antes queriendo aprehenderlo, ocultando los apuntes acerca de dichas experiencias o como hiciera el inglés Samuel Pepys respecto a su Diario (edición moderna, 1970-1983), poniéndolos a buen recaudo, una manera práctica de inmortalizar en más, en menos, la extensa historia del puerto hacia las generaciones subsiguientes.

No obstante, queda mucho todavía por explorar en el referido tema y pueda sea otro narrador quien se encargue de tomar la posta de lo iniciado por José María Arguedas en El zorro de arriba y el zorro de abajo (1971); continuado casi cuarenta años después por Alejandro y los pescadores de Tancay (2004); vendrían luego las fallidas, en tanto apresuradas en publicarse Llora corazón (2006) y Lancha varada (2007) de Fernando Cueto; de nuevo reaparecía Muñoz Terrones dando a conocer Los apuntes de Alejandro (2009); arribando dos años más tarde en relación a ésta la novela Hombres de mar (2011) de Oscar Colchado Lucio. Según puede concluirse de manera preliminar, en lo sucesivo, han quedado abiertos los cauces por donde se puede avanzar con distinta seguridad, casi respondiendo y dejando arcaico el planteamiento teórico a cargo del estudioso Saniel Lozano Alvarado. ${ }^{5}$ Ya depende de cada novelista experimentado o narrador en ciernes si toma el desafío o lo rechaza de plano al orientarse hacia otros extremos aunados a diferentes temáticas. Solo advertiremos que debido a su fluida como prístina manera de escribir, a veces pareciendo espontáneamente sencilla, lo más difícil, en verdad, engañosamente sencilla, aún abordando una realidad tan compleja, Braulio Muñoz Terrones ha puesto la valla demasiado alta.

\section{NOTAS}

1 Muñoz, Braulio. Los apuntes de Alejandro, Río Santa Editores, Chimbote, primera edición 2009, 218 páginas más un epílogo a propuesta del editor. En esta edición nos hemos basado para obtener las citas del presente ensayo.

2 Para una mayor profundización sobre mis puntos de vista en torno a la novela Alejandro y los pescadores de Tancay (primera edición, 2004; segunda edición, 2005) remito a los interesados a la siguiente página web: http://tierradepromision.blogspot.com/2006/09/el-realismo-magico-en-la-novela.html.

3 Específicamente nos referimos al distrito de Chaclacayo, de triste recordación en la crónica policial, por cuanto allí quedaba la casa donde fuera asesinado Luis Banchero Rossi, el multimillonario magnate de la pesca en los años 60, tan vinculado a Chimbote y todo un "inspirador" de otro personaje en APT, al extremo de afirmarse que con la muerte de aquél, las causas permanecen hasta ahora en el misterio, esta actividad decayó notablemente.

4 Recordemos, sin caer en el exceso ni en el prurito del conocimiento que la novela Alejandro y los pescadores de Tancay tiene el significativo subtítulo de "memorias".

5 En la página 29 de su libro El rostro de la brisa. Chimbote en su literatura, Editorial La Libertad, Trujillo 1992, este reconocido profesor universitario sostenía que el puerto sigue "a la espera del escritor que refleje el medio y la peripecia vital del hombre". 


\section{EL SURREALISMO Y LA SUBJETIVIDAD EN UNA PIEDRA DESPLOMADA DE CÉSAR QUISPE RAMÍREZ}

Más allá de la muerte de André Breton (ocurrida en 1966), el sumo pontífice del surrealismo, todavía quedan rezagos, en pleno siglo XXI, sobre las lecciones dadas por éste cuales recetas infalibles para hacer poesía. Empero, como bien apunta el prologuista Camilo Fernández Cozman, a radical diferencia de cuantos podemos nombrar unos detrás de otros, calificándolos de seudo surrealistas bretonianos, junto a sus títulos correspondientes, César Quispe Ramírez (Chimbote, 1977) se ampara en la corriente vanguardista de origen francés para, desde allí, dar el cualitativo salto en procura de afinar su propia voz, búsqueda con frecuencia rematadamente incierta, conforme lo demuestra por medio de Una piedra desplomada (2010) ${ }^{1}$, cuyos epígrafes, obtenidos de Thomas Stearns Eliot y Ezra Pound, son por demás expresivos para entender hacia donde está apuntando hoy en procura de dar en el blanco.

Aunque el volumen no se encuentra dividido en partes, los veinticuatro poemas numerados y titulados solo en romanos, podemos agruparlos en tres, a partir de lo común respecto a sus temas. En el primero está la voz del hombre intentando explicarse las grandes trascendencias de la carne yendo por encima de lo espiritual o desbordando las cadencias de lo inmediato, cuando todos encuentran lógica hasta en el absurdo de la existencia y el poeta, siendo como es, humano al fin, está en la obligación de hallar una salida en medio del caos. Lo dice desde el primer verso, dubitativo respecto al mañana: qué haré cuando levante mi camisa/ y mi caja toráxica observe el cielo azulgrís/(p.19). Esto es, la seguridad no existe en un mundo donde se ha perdido la dirección respectiva, donde cada quien está condenado a caminar de tumbo en tumbo, donde orientarse puede solo significar en un momento algo importante antes de regresar a ese extremo de la nada, relativizándolo todo, aun siendo materia tangible ante nuestros ojos entumecidos: esta es la misma calle/la misma hora/ el mismo cuello de cisne que gira/ (p.45) o se diluye previo al arribo de cuánto se tiene por un síntoma evidente del pánico extendiéndose entre las praderas: no busques el dolor de los troncos/si hay un fuego haciendo luz como un pájaro/(p.36), ni siquiera se encuentra un sentido lógico en el amor representando el amparo frente a la infelicidad rondando las esquinas, sembrando la incertidumbre en las habitaciones y el desaliento por las tardes de cualquier día en el almanaque: ante tu registro/ mejor es el silencio de este cuerpo/porque ya aprendiste a deletrearme/(p.28).

De allí que la voz de Quispe Ramírez suene como perteneciente a otro tiempo. Porque el esfuerzo de apoderarse, quintaesenciar, captar lo mejor del 
surrealismo, le ha permitido quedarse apenas con unos cuantos elementos dividiendo a las palabras en fonemas con pequeños espacios sobre la página en blanco, símbolos ortográficos adicionales, aparte de la eliminación de las letras mayúsculas, pudiendo entorpecer la tranquilidad hasta descender cuales cascadas de agua sobre un panorama difuso. Despojado de la condición casi sacra de otros siglos, el poeta va a insistir en la precisión de una voz rotunda como desesperada siguiendo tal vez lo planteado por El grito (1893), el famoso cuadro del pintor noruego Edvard Munch: todo ha caído

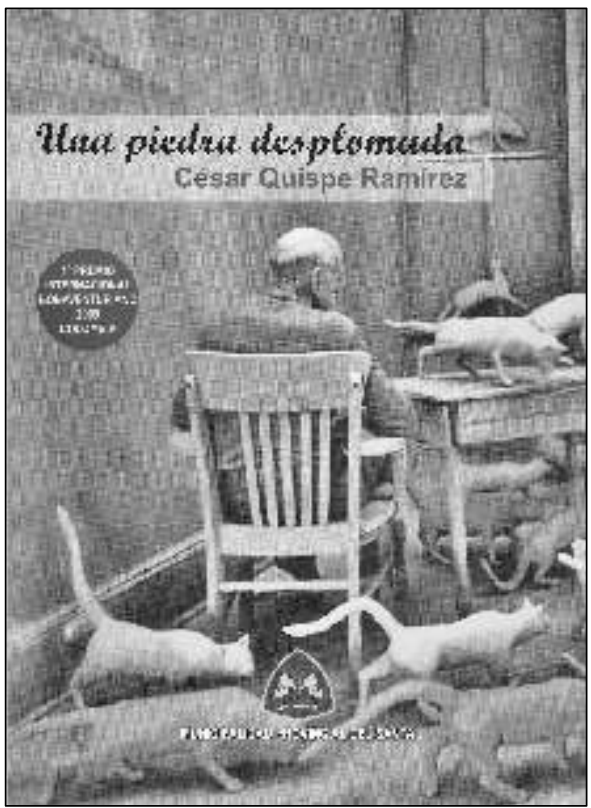
a tierra/se ha clausurado el aire/ se ha sepultado al astro ciego/ (p. 43) y aun siendo la mujer de siempre acompañándole, quiere, al mismo tiempo, proyectarse a derribar las fronteras de cuanto se considera es lo estipulado: yo quería verte en el espejo/donde la vida retorna/a su forma exacta/ (p.32), ampliándose luego hacia una percepción distinta de la urbe donde vive o ha vivido, concibiéndola cual alucinada en esos instantes de aburrimiento y de zozobra: ;oh ciudad contra el cielo!/ así te quejarás en la confusión de la noche/después de haber desgastado el dedo inquisitivo/ (p. 43). O supone también hay detrás de las cortinas una salida al oprobio existencial de habiendo nacido libres, ni siquiera en la vigilia o en pleno sueño, conseguimos escapar a tan semejante y funesta condición: nunca se sabe si el que camina por la misma calle/ es amigo o enemigo/ y a no se puede tener el mismo color enajenado/(p.39).

En el segundo grupo temático se halla el poeta recurriendo al ser amado. En este sentido, como todos, como nadie, como pocos, César Quispe acude a una mujer habitando en la nubosidad de lo oscuro, por tanto, imposible de nombrarla, debe esperar acaso la prolongación del tiempo para que, recién puedan encontrarse, conforme es debido. La expresividad fluye rotunda hasta cercenarnos el aliento: qué será de la tarde/ si no puede apagar la brasa de tus labios/ (p.47). O podría también tratarse de una mujer inventada y no redactarle una elegía según lo hiciera Xavier Abril, otro surrealista de viejo cuño, sino más 
bien escribirle bajo todo conocimiento de causa: ahora que te amo/ eres la miel de los racimos dulces/ eres una ave nocturna que lleva en el vientre/ una lámpara limpia de cara al sol/ (p.24) o se expresa para volverla en un ente concreto, digamos, más observable, tornándola en corpórea, capaz de multiplicar la especie humana: siempre diste tu aire tu llanto de ollas en la cocina/ tu dialecto ennavajado y suculento/ para que la estirpe siga buscando la brillantez de las piedras/ (p.29), pues, la poesía suele desbordar los límites, incluso traspasar los del escándalo para instalarse donde menos se le espera, desafiando decididamente las convenciones sociales: vístete y huye/y déjame tu fe y tu estrella/ para resistir en la alambrada/ como una pequeña boca incorruptible/ (p.40). Lo decía el hiperbolizado Luis Hernández Camarero: "nunca te amaré porque ya te amo", o sea, ni modo, la poesía se convierte en una herramienta válida para afrontar el dolor y la desazón, respectivamente.

Dentro del tercer grupo de poemas, incluidos en Una piedra desplomada, cuyo título deriva de los versos donde el idílico entorno acaba desacralizado: sin saber que el heroísmo lo hemos heredado/ de una/ piedra desplomada/(p.21), se hallan aquellos presentando un giro hacia la voz colectiva. Quispe Ramírez toma la necesaria distancia de cuánto hasta entonces osó avanzar para, desde allí, echarse a caminar por aquellos senderos donde pueda sentirse menos solo, sin tampoco adquirir el tono ecuménico, orientándose falsamente a lo social y a lo político. Se trata más bien de alguien buscando la ansiada comunión con el otro, aunque desde un principio le dice: déjame abandonar la cama/ si estoy pegado al insomnio/ (p.23), porque entendiendo esto como una advertencia ante lo venidero, las cosas confluirán hacia el lado donde más se requiere la urgente presencia de aquel para evitar derrumbarse sobre la incertidumbre y el vacío: no me digas que la tierra es menos habitable/ y que los hombres abominan hoy más que nunca la sonrisa/ (p.38). No obstante, tampoco ello es garantía de nada ni representa algo por encima del común, el asunto se torna ordinario como el hambre haciendo mella en los estómagos: cuando abren sus bocas escupen la miseria/ masticada por las máquinas/ esquizofrénicas de su tiempo/ (p.30), derivando enseguida hacia la condición donde quedamos todos sometidos a las órdenes, diciendo son "los otros" el producto de nuestra inocultable naturaleza: ahí viven ellos bajo el saludo/frenético de los cielos/ trabajando bajo el sudor de las agujas de los relojes/ (p.49).

También hay poemas independientes de los tres grupos. Por allí expresan unos conceptos alejados de lo sombrío y manifiestan una sonoridad repleta de significados. En unos tiende hacia el erotismo, sutilmente expresado: yo devoré 
tu pan/ en la humedad de tu seno/(p.50), en otros afirma la posibilidad de extraviar el sentido sobre dónde hallarse en todo momento: miró al jardinero/ y en su estómago se diluyó un irreconocible silencio/(p.22), en unos se orienta por la personificación como recurso poético, aun cuando no se trate del poeta hablando en primera persona: soy un avión que dirige el vuelo de los pájaros/ soy un tren que avanza con su bocina devorando los rieles/(p.25), no faltando también aquellos donde efectúa una variación, cosa no frecuente: yo quería verte en el espejo/ con tus ojos indígenas iluminados por la luna/ (p.35) hecha sobre el verso de un poema anterior inserto en el mismo volumen: yo quería verte en el espejo/donde la vida retorna/ a su forma exacta/ (p.32). Esto va acorde con el tono general adoptado por Quispe Ramírez, siguiendo el ejemplo de Carlos Oquendo de Amat, quien se anticipó en dejar bien afirmada una lección a través de sus Cinco metros de poemas (1927), volviéndose (todavía es) el más grande de los vanguardistas peruanos (exceptuando a Vallejo, que abominó del surrealismo, al punto de haber escrito una recordada "autopsia"), demostrando con creces el correcto modo de insuflar dicho aliento en la poesía de cada quien. Todo esto se halla evidenciado en los numerados, pertenecientes al primer grupo: poema I, poema VIII, poema XI, poema XIII, poema XV, poema XVII, poema XX, poema XXI; de los integrados al segundo están: poema $\mathrm{V}$, poema IX, poema XVIII, poema XXII; hasta cerrar con los del tercero: poema IV, poema X, poema XVI, poema XXIII, respectivamente.

Ganador con este libro en el 2009 del Primer Premio en el V Concurso Internacional Bonaventuriano de Poesía, organizado por la Universidad San Buenaventura de Cali (Colombia), César Quispe Ramírez ha demostrado un deseo persistente de no solo internarse en los fueros del surrealismo sino desde allí emerger hacia otros ámbitos, las próximas cinco esquinas, como la revista que dirige, donde su voz pueda sonarle más suya, separada de aquellos donde los opuestos se juntan formando expresiones un tanto extrañas a cualquier posible lógica: no te inquietes/si oyes el grito sonoro/de un barco que se muerde/ (p.33) o en este otro: no tiene pudor en sus pasos/ cuando calienta en sus alas/ (p.41). Se entiende ha decidido en, sobrepasando cualquier posible atingencia, evitar quedarse en ser un mero epígono y, desde sus primeros poemas, en realidad desechables, carentes de valor literario, llegando a los eminentemente narrativos de El abrigo de mis sandalias (2006), avanzando por El vuelo de la mosca (2007) hasta llegar a Una piedra desplomada, en la víspera de otro poemario que, según sabemos, viene hace algún tiempo preparando, bajo el título de Reino interior, hay mucho recorrido hasta derivar en una voz, "convergien- 
do entre lo corporal y la abstracción" -escribe Vanessa Vera- (donde) "el hombre apela siempre a existir, a ser afirmado por lo que está más allá de él; este poemario es un recorrido ontológico en busca del origen que la voz lírica halla en imágenes simbólicas como el árbol o el espejo". '

En esto de la temática es poco surrealista y, por el contrario, el también fundador-director de las recordadas revistas "Tinta Libre" o "Eleusis", prefiere adentrarse en la exploración de dichas posibilidades. Lo ejecuta en la absoluta distancia y en medio de la constante vorágine de cientos de (seudo) poetas que, creyendo en la necesidad de los chisporroteos y las jitanjáforas ${ }^{3}$, despliegan hasta lo indecible a fin de mantenerse en medio del bosque; mientras Quispe Ramírez, como lo resaltara el ilustre Javier Sologuren respecto a su discípulo el prematuramente desaparecido Javier Heraud, pone todos sus ánimos para insertar dentro de su sensibilidad cuánto dejó en la historia de la poesía aquella corriente de cultores tan respetados y, en paralelo, se esfuerza en convertir todo ello en una parte sustancial de su creación. Claro está, emergiendo de tales raíces, no se conforma con solo tenerlas o dominarlas sino las somete a cómo las quiere y anhela, permitiendo recién después la irrupción de versos donde, de a pocos, empieza a surgir una voz cada vez más autónoma. Sin duda, en tanto no se confíe de sus primeros logros, le queda mucho todavía por hacer en este género excelso. Todo depende de su propia disciplina, su pormenorizado estudio.

\section{NOTAS}

1 QUISPE, CÉSAR. Una piedra desplomada, Ornitorrinco Editores con el auspicio de la Municipalidad Provincial del Santa, Lima, Octubre del 2010, 51 páginas numeradas. En esta edición se fundamentan las citas textuales del presente ensayo.

2 VERA, VANESSA en la contra carátula de Una piedra desplomada, Ornitorrinco Editores con el auspicio de la Municipalidad Provincial del Santa, Lima, Octubre del 2010.

3 Así denominó Alfonso Reyes, a partir de una estrofa del cubano Mariano Brull, acertadamente, creemos, a los versos tan frecuentes en la poesía contemporánea donde prevalece el sonido, el juego de palabras y el absurdo. 


\section{VORÁGINE ARGUMENTAL EN EL CAMPEÓN DE MARINERA DE RICARDO VIRHUEZ VILLAFANE}

Para asumir la escritura extensa con atisbos de narrativa corta, el apuro -mal entendido como un ingrediente adicional a dicha especie literaria- termina siendo una verdadera traba, por cuanto, el fluir de la materia se convierte en algo deleznable, impropio y hasta frívolo. No se puede incursionar en dicho extremo si, en la víspera, se ha olvidado aceptar la naturaleza lenta de toda novela, con el reconocido tiempo muerto donde aparentemente nada sucede, más todavía si el tema abordado lo exige en demasía. Entre muchas otras, ésta es una de las características de la novela haciendo extensiva la diferencia en relación al cuento, nunca en el procedimiento efectuado por Ricardo Virhuez Villafane (Lima, 1964) en su obra El campeón de marinera (2011). ${ }^{1}$

Cosa distinta es hablar acerca de la, tantas veces mentada, eliminación de las fronteras entre los respectivos géneros literarios de modo tal ¿que un cuento parezca novela y una novela parezca cuento? Siguen las dudas aflorándonos por doquiera en la medida de, intercambiando ambos, solo a partir de sus características sustanciales, en la práctica tendríamos algo híbrido donde sobre el tiempo en uno y falte el mismo en el otro. No es similar a embarcarse en El goce de la piel (2005) de Oswaldo Reynoso o en Bonsái (2007) de Alejandro Zambra, para mencionar solo a quienes están más cercanos desde lo cronológico. En la novela corta del peruano resultan exactas las pocas páginas, considerando de habérsele agregado más hubiera resultado farragosa, repleta de fragmentos sobrantes e inútiles y, en la del chileno, aquella poética sirviéndole de sustento, culminaría en una falsedad como opción narrativa al negarse a sí misma para hacerse valedera. En la primera, lo preciso y exacto resultan necesarios; en la segunda, forma parte del juego lúdico a la cual es tan entregada la narrativa de hoy, en particular, siguiendo la línea impuesta por Manuel Puig y Vargas Llosa, padre, quienes apelando a la parodia, en Boquitas pintadas (1969) y Pantaleón y las visitadoras (1973) respectivamente, demostraron el uso que podrían darle a los recursos ajenos a la literatura, pertenecientes muchos de ellos a la cultura de masas, llámese recortes de periódicos y revistas, cartas, telegramas, informes, entre otros.

Distribuida en tres largos capítulos, a su vez integrados de una serie de fragmentos separados mediante espacios en blanco más un epílogo, narrada en la primera persona del singular y del plural, con mudas repentinas hacia la tercera persona, debido a las exigencias expresivas de la trama, intercalando además los tiempos presente y pasado en orden sucesivo de complemento mutuo, 
técnicamente llamada vasos comunicantes, donde "con un lenguaje coherente, -escribe Julián Rodríguez- recrea con precisión los sinsabores de una historia de amor y una historia de pasión", ${ }^{2}$ El campeón de marinera comienza a través de una rotunda frase de entrada a la ciudad donde vivía Benito Tafur, el protagonista de origen trujillano, en su condición de emigrante: La factoría donde yo trabajaba en Nueva York estaba llena de personas interesantes (p.7). Sin embargo, en el afán por hacer realidad el sueño americano, formando parte de la comunidad de latinos residentes en la tierra del Tío Sam y de Jack London, su vida parecía estar resuelta, nada por qué preocuparse respecto al mañana hasta que, en medio de los ajetreos queriendo estudiar una carrera profesional, trabajando en un restaurante y estar con Megan, su novia gringa, le sobrevendrá una experiencia alterándolo de lado al lado, tras escuchar la música ondulante de una marinera -bautizada así, no olvidemos, por el literato y periodista Abelardo Gamarra, quien firmaba como El Tunante- percibe la intensidad insoslayable de un terremoto interior. Lo precisa: Mi corazón se detuvo y, de pronto, se inflamó de una manera extraña (p.31).

A partir de entonces, decide abandonar todo cuanto consideraba le pertenecía en aquella ciudad y volver en busca del terruño dejado, inscribiéndose en la Academia Chacón, empezando a practicar obsesivamente dicho baile en sus armoniosos pasos y con el pañuelo al aire. Tafur quiere alcanzar a dominarlo, sentirlo en la viva piel, percibirlo en el trance de ser quien es, relacionándose de paso con Lucía Castillo, su pareja de baile durante varias clases, incluso se da lo inevitable: le dio un beso en la mejilla, tan cerca de la boca que a Benito le pareció sentir sus labios húmedos y suaves (p.28). Esto es, se perfilaba el anuncio de una historia cargada de sensualidad acorde al ritmo de ese baile insinuante, de coqueteo entre la mujer y el varón cuando, irrumpe el recuerdo de Megan -un personaje acartonado aparte de falso en su hablar, demasiado fluido en español para ser norteamericana de nacimiento- llamándolo por teléfono, obligándolo a establecer una prudente distancia, terminando después la relación sentimental ("amor de lejos felices los cuatro" reza la sabiduría popular), quedándose junto a Lucía, quien a su vez teniendo un enamorado, cambia de actitud con Benito, instaurándose en él un enorme desconcierto, no sabiendo a qué atenerse ni cómo hacer frente a la inesperada situación.

Allí resultará providencial la aparición de Jimena Dianderas, otra joven interesada en aprender a bailar marinera, de carácter más bien montaraz, un tanto díscolo, el narrador la describe de un solo tajo: Ella no sería mujercita de nadie (p.50), aunque no por eso se mostrará menos asequible a Tafur. Habiendo 
quedado Lucía internada en el Hospital Belén, a causa de una repentina enfermedad, no diagnosticada, la relación siendo pareja de baile empieza de casualidad con Jimena, derivando en una de mayor comprensión que va incrementándose en los días, pese a los esfuerzos de él por como sea evitarlo y los de ella estando en lo mismo, al suponerlo un varón de bastante experiencia amorosa, según en efecto lo es, sobre todo habiendo vivido en los Estados Unidos durante siete largos años. De nuevo, el baile, cuyos orígenes se remontan a haber sido o ser una forma de adorar a los dioses, honrar a los ancestros e inclusive crear magia, es llevado también a los tiempos del erotismo y la seducción, donde las parejas, a similitud de lo que sucede en el cine o en la pantalla chica respecto a los actores terminando por pasar la barrera casi invisible entre lo real y lo ficticio, acaban también sumergidas en la pasión.

Empero, el clímax en El campeón de marinera se inicia tras la convocatoria oficial al concurso nacional de marinera que tendría lugar en el no menos famoso Coliseo "Gran Chimú". Es decir, el nudo de la novela se ubica en un contexto histórico, social y cultural específico porque, bien sabemos, la marinera del norte peruano está relacionada intrínsecamente con Trujillo. Es inherente a dicha ciudad, conforme lo será para Benito Tafur y Jimena Dianderas, quienes, decidiendo participar en tal evento, se orientan desde ya por incrementar la frecuencia de sus ensayos, importándoles en nada el agotamiento físico que sienten: solo piensan en ganar. Y, por eso, se mantendrán juntos hasta la noche de aquella final de finales, donde competían únicamente los mejores entre los mejores, cuando en ella irrumpe: Miró a Benito como se mira a un hombre. Lo deseó, en ese momento, más que a nada en el mundo (p.90), toda una conexión erótica prolongándose entre los pasadizos del coliseo, incrementándose hasta niveles imposibles de dominar tras el veredicto del jurado, señalando a ellos como la pareja ganadora. El maestro de cere-

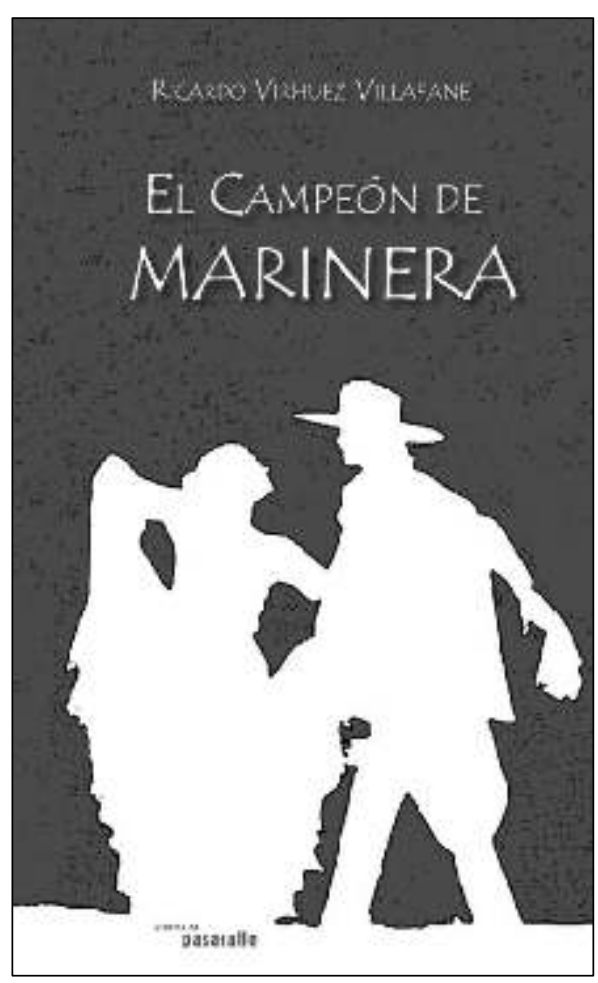


monias describe el tempestuoso momento: Están al fondo, besándose, y todavía no se enteran de que son los campeones nacionales de marinera (p.92).

A todo este esqueleto argumental, narrado mediante un lenguaje directo, lacónico, seco, con algún rasgo apenas perceptible de poesía, se adicionan las innumerables experiencias en Nueva York vividas por Benito Tafur, el personaje principal, a quien el profesor Crisóstomo Gamboa ha calificado de un ser desarraigado, ${ }^{3}$ acostumbrándose a estar en un lugar de costumbres opuestas, conociendo a personas de distinta nacionalidad, hallándose entre éstos Francisco Tello, puertorriqueño; Julia Morales, dominicana; Rose, otra enamorada gringa, habiendo trabajado de pintor, cuidador de casas y últimamente en una factoría, que era el nombre que daban a las fábricas (p.16) o Sergio Rodríguez, Manuel Chacón, su primo y dueño de la academia, Carolina del Águila, Franciles Sánchez, Maricarmen Chávez, Adriano Vásquez, Sonia, Fabián, Rubén, mezclados a la mención de personajes reales, viviendo en la capital de la Región La Libertad, gestores de tal danza, entre otros nombres, dispersándose por distintos puntos de la denominada "ciudad de la eterna primavera" o de la propia "capital del mundo" como cantaba el Gran Combo de Puerto Rico en relación de Nueva York: recorrí Queens, Bronx, todo Manhattan y Brooklyn en sus buses y trenes, y me engolosinaba viajando en ferry hasta Staten Ilsand (p.13). O sea, la materia narrada es mucho más amplia de cuánto se ha consignado en la edición de noventa y nueve páginas nada menos, similar a haber decidido recortar fragmentos, resumir otros, quedándose con los necesarios de acuerdo a la perspectiva de Virhuez Villafane, también incurriendo en lo mismo en Volver a Marca (2001), su obra anterior, privándonos del gusto por disfrutar, sin movernos de nuestra casa (una de las grandes ventajas de la lectura), de todo lo representado volviéndosenos tan fascinante.

Debido a conocer una parte sustancial de su trayectoria, al extremo de haber orientado esta novela al modo de un "pretexto identitario -escribe Gonzalo Espino- para discutir o poner en debate el espectáculo de la marinera", ${ }^{4}$ nos resulta difícil entender por qué quien durante años fuera corrector en el diario "La República” y editor general del semanario "Noticia Hispanoamericana" de Nueva York ha precedido de esta forma, adoptando más un tono periodístico, casi de reportaje, en nada cercano a El viejo y el mar (1952) de Ernest Hemingway, el antecedente más preclaro en referencia a dicho estilo, ni siquiera de crónica, aproximándolo quien sabe a Jorge Edwards en Adiós poeta (1990), dejándonos en ascuas frente a una promesa incumplida. Los personajes, sean principales o secundarios, nunca alcanzan a delinearse de manera panorámica, jamás abandonan su condición de ser meras siluetas desfilando de largo, puestas 
allí siguiendo terminantes órdenes del autor, dando su contribución episódica al argumento general, desapareciendo luego sin dejar rastro alguno e inclusive, en el estricto plano de la ficción, parecen no haber existido nunca. Solo quedan Lucía Castillo, Jimena Dianderas y Benito Tafur respirando a duras penas, sometidos a continuos cambios, no dándoles tiempo a pensar (lo psicológico) ni menos disfrutar a plenitud los momentos de placer (lo erótico) a los cuales son tan proclives, aspecto acorde en sí a la misma naturaleza de la marinera como baile, partiendo Tafur nuevamente de Trujillo con destino a Nueva York donde piensa poner una sucursal de la Academia Chacón.

El ritmo impreso a El campeón de marinera acaba siendo un notorio defecto, en nada aportando a la creación de la atmósfera o el ambiente más propicio albergando a la historia central y sus líneas correspondientes. De hecho, si Ricardo Virhuez hubiera preferido demorarse, agregándole detalles, quitándole lo intenso de la vorágine argumental e inmediatez estructural, menguándole el extremo tragicómico y dulzón de algunos fragmentos, tendiendo hacia la inverosimilitud, ¿la nostalgia por el terruño será realmente un poderoso motor obligando a dejar todo? y al facilismo, precipitándose en la ingenuidad de algunas escenas, estaba de sobra llamada a convertirse en una "novela de la marinera" como El corrido de Dante (2007) de Eduardo González-Viaña lo es de la emigración en los Estados Unidos o Sangama (1942) de Arturo D. Hernández, entre las novelas "de la selva”, en el caso del Perú. Tenía en sus manos el también director de la "Revista Peruana de Literatura" un buen tema (casi) inédito en la narrativa de nuestro país, pero (evidencia de que no basta poseer ello para escribir una obra de calidad), tomando distancia de lo complicado, apuntando acaso de manera errada lo más pronto a ser leído, se inclinó por lo rápido, lo sucinto y lo breve. O quizás pensando en abordar el subsiguiente proyecto, dejó escapar la posibilidad de marcar un derrotero en el bifurcado camino a la enésima potencia de la literatura peruana.

\section{NOTAS}

1 VIRHUEZ, RICARDO. El campeón de marinera, Editorial Pasacalle, febrero del 2011, 99 páginas. En esta edición nos hemos basado para obtener las citas de nuestro ensayo.

2 RODRÍGUEZ, JULIÁN. El campeón de marinera, en: http://julianeltemerario.blogspot.com/2011/04/elcampeon-de-marinera.html, consulta del día 08 de noviembre del 2011.

3 GAMBOA, CRISÓSTOMO. El campeón de marinera: novela del desarraigo, en: http://revista-peruana-deliteratura.blogspot.com/2011/04/el-campeon-de-marinera-novela-del.html, consulta del día 08 de noviembre del 2011.

4 ESPINO, GonZALO. Ricardo Virhuez y El campeón de marinera, en: http://gonzaloespino.blogspot .com/2011/04/ricardo-virguez-y-el-campeon-de.html, consulta del día 08 de noviembre del 2011. 